\title{
Eco-critical aspects in the writings of Toni Morrison's The Bluest Eye and Alice Walker's The Color People fictions
}

\author{
A.Vidhyarathi
}

\section{Introduction}

Black women writers like Toni Morrison and Alice Walker focus the sufferings of black women through their black female characters in their fictions. The black women novelists Toni Morrison and Alice Walker have discussed the spatial inequalities faced by black women in their works The Bluest Eye (1970) and The Color Purple (1982) respectively. The sufferings of black women are categorized as sexual violation, racial conflicts, verbal abuse, and psychological harassment and so on.

\section{Spatial Inequalities in The Bluest Eye}

In Toni Morrison's The Bluest Eye, The protagonist Pecola, a dark-skinned girl undergoes a lot of sufferings like sexual abuse, verbal abuse, racial conflicts and finally she becomes mental imbalanced. Though she receives the support of the other black girls, Claudia and Frieda who are at her age, Pecola is rejected by her mother Pauline who always admires the white master's baby. When she reveals her puberty to her mother, Pecola is not instructed as how to secure herself from the external atmosphere. Her mother addresses that immediately on seeing her face at her birth; Pauline becomes upset on her ugliness. From that onwards, Pauline ignores her daughter and adapts the unmotheringness, Being not caressed by her mother, Pecola lacks her familial support. Pauline's dejection is owing to her default in her limbs. The author describes the situation of Pauline as she adopts 'passing on' approach when she finds happiness at being called as "polly" by the white master's family. Pauline satisfies with the appreciation and feels comfortable by ignoring her drunken husband, Cholly Breedlove and her innocent daughter, Pecola. Pecola loves Shirley Temple for whiteness and beauty and believes that blue eyes ate the symbol of beauty and acceptance. Her rejection by the brown skinned boy, Junior who injured Pecola with the help of his white cat and the phrase "you black bitch" uttered by Junior's mother leads her to be in a state of inferior sense. Being humiliated by the white race, Pecola recognizes the racial indifference and realizes that achieving "blue eyes" is her destination. While she is washing the dishes, Pecola is being seduced by her father Cholly when his father is in a drunken state. When she conveys to her mother about her situation, Pauline is not keen to her and console her. Pecola is condemned by the society that she is responsible for being raped by her biological father. Being ignored by the society, Pecola lacks recognition both by her family and her community. At last, she seeks the support of the priest Soaphead Church who consoles her by leading Pecola to offer meat to dog. He finalizes that if the dog accepts Pecola would receive her blue eyes from God. Pecola poisoned the dog and become mad. Pecola believes that her madness erases her alienation from the family and community but will help her to achieve her blue eyes.

\section{Spatial inequalities in The Color Purple}

In Alice Walker's the Color Purple, Celie, the protagonist uses the epistolary form. She addresses letters in the name of God. She is twice sexually abused by her stepfather Alfonso whom she calls 'pa'. Immediately after the birth of Celie's brother, her stepfather demands her mother for sexual intercourse. When her mother rejects of being tired with her delivery, Alfonso moves on to Celie who is at the age of twelve. Celie gives birth to two children, a boy and a girl but were sold immediately after their birth. She believes that they might die. Celie is in the position of safeguarding her sister Nettie. Being bored with Celie, Alfonso surrenders her to Albert who is at his age in the name of marriage. Her step father addresses Celie that she acts like a cow and is fit for only household activities. Celie is abused both verbally and sexually by Albert whom she refers as Mr._. She protects Nettie from the abuse of both her step father and her husband Albert. Finally, Nettie rescues herself from Albert and has been supported by the black couple, Corrione and Samuel who adopts Celie's children and named them as Olivia and Adam.

Throughout the novel, Celie is humiliated by her stepfather and her husband. Albert's verbal abuse on Celie as "You fit for nothing" makes her to feel inferior. Celie is often criticized for her looks and been compared with Shug Avery, a daring character and the mistress of Albert. She feels the admiration towards Shug who teaches her to love her body. 
Celie's step son Harpo insults and beats Sophia but Sofia repeats the same to Harpo. When she is racially suppressed for beating the white mayor and is sentenced for twelve years of imprisonment, Sofia becomes meek and mild. And thereafter, she accepts the situation the way it comes. Squeak, the white girl who loves Harpo and becomes the rival of Sofia. She makes quarrel with Sofia for possessing Harpo as her own. Yet, she plays the role of sisterhood and offers herself to her own white uncle for seduction while demanding for relaxation of imprisonment for Sofia.

\section{Conclusion}

Walker's description about the characters like Celei, Nettie, Shug, Sofia and Squeak in the Color Purple proves that gender difference and the oppressed context of black female characters. Lack of familial support in Celie's and Nettie's upbringing, lack of communal acceptance in Shug leads her to be a daring character and lack of recognition in society ends in Squeak's indifferent attitude and Sofia's adaption of meekness. The context of black female characters proves the spatial inequalities in Such as lack of both the black women writers Toni Morrison and Alice Walker begins their themes in the mentioned novels by representing the protagonist as meek characters. The black female characters in the novels like The Bluest Eye and The Color Purple, undergoes verbal abuse, sexual abuse and psychological abuse. They find their inequalities in familial space, communal space and work space. The novelists empower their characters. Like Nettie in The Color Purple through education and sisterhood bonding in characters such as Pecola and Claudia and Frieda in The Bluest Eye, Celie and Nettie, Celie and Shug, Celie and Sofia, Sofia and Squeak in The Color Purple.

\section{Reference}

[1]. Morrison, Toni. The Bluest Eye. New York: Random House, 1970. Print

[2]. Walker, Alice.The Color Purple. New York: Harcourt Brace Jovanovich, 1976.Print. 